\title{
Case Study on Factors Affecting Training Need Assessment in Jimma University College of Agriculture and Veterinary Medicine librarians
}

\author{
Alemayehu Abebe ${ }^{1} \quad$ Marta Hailemariam ${ }^{2} \quad$ Alemu Tesfaye $^{3} \quad$ Tesema Tesfaye $^{4}$ \\ Abduselam Sherif ${ }^{5}$ Waktole Bayisa ${ }^{5}$ \\ 1.Batu Fish and Other Aquatic Life Research Center, East Shewa, Batu, Ethiopia \\ 2.Department of Rural Development and Agricultural Extension, Jimma University, Ethiopia \\ 3.Department of Rural Development and Agricultural Extension, Mizan-Tepi University, Ethiopia \\ 4.Southern Nations, Nationalities and Peoples Region, Agricultural and Natural Resource Office, Ethiopia \\ 5.Oromia Agricultural and Natural Resource office, Ethiopia
}

\begin{abstract}
Training need assessment is also the process of collecting information about an employees or tasks that helps to specify the training need or performance deficiency. This study examined to assess factors that affect training need Assessment in Jimma University College of Agriculture and Veterinary Medicine librarians that used questionnaire, interviews, observation and document review as instrument of data collection. Simple random method was used to select samples from the target population and the study employed quantitative and qualitative data types from primary and secondary data source. The quantitative data analyzed in descriptive (frequency, percentage) by SPSS version 20 and presented in table and graph forms. The qualitative data were also analyses in systematic narration. The results of this study revealed that there is not a regular system on delivering training program and weak in supervising the employees by higher manager. Regarding on the training every decision is held by the higher manager without a systematic and detail information gathering about individual, there performance and the level of their skill. The survey data revel that lack of attention from the higher manager on training need assessment due to workload, lack of proper training program and Lack of facilities and logistics were the main reason for the failure of training activities in library. Therefore, Jimma University College of Agriculture and Veterinary Medicine should be provide attention on training need assessment the lead to prepare any training for the right people at the right time for filling the gap to create a good work environment that directly help to improve library service.
\end{abstract}

Keywords: Training, Training Need Assessment, library, JUCAVM

DOI: $10.7176 /$ JTHS/42-01

Publication date:July $31^{\text {st }} 2019$

\section{INTRODUCTION}

\subsection{Back ground and justification}

Training is a learning process whereby people gain the essential skills and knowledge to improve the attainment of organizational goals. The aim of employee training is to increase the capabilities and potential of employees in carrying out their duties. Harris and De Simon (1994) states that in order to meet the current and future needs, the organization should begin training and development activities when an employee joins the organization and continues throughout his/her career's. Training is a short-term educational process and utilizing a systematic and organizational procedure by which employees learn technical knowledge and skill for a definite purpose. For employees to carry out their duties effectively and efficiently, they must have the relevant skills, knowledge, values, attitudes and competencies as well as understand their organization's culture.

People in the organizations are valuable assets that help the organization to implement and achieve its corporate strategies and objectives successfully. In modern organizations invest a huge amount of money in training and learning programs (Salas et al., 2012). Before sending them in training programs it is very important to identify the needs of the employees. Training Needs Assessment (TNA) is a valuable tool to provide a detailed picture of an employee's knowledge, skills and abilities. As we ahead the second decade of the 21 st century, change remains an enduring theme. In order to survive and prosper, organizations in the private and the public sectors will need to respond in a timely and flexible way to social, technological, economic and political change. This means ability to cope with the external and internal requirements will decide the organization's survival and growth. This implies that existing and new staff will need to acquire new knowledge, skills, attitudes and perspectives on a continual basis (Roger and Jim, 2009).

International Federation of Library Associations (IFLA), in its Standards for Library Schools; stated that the core curriculum should consist of the fundamental subjects that all students should master first. While the traditional core curriculum for the library and information science should include book selection, cataloging and 
classification, reference work, administration and management of libraries, history of books and libraries, research methods, and libraries in the society (including communication). In Ethiopia School library development has never been given attention and lately even declined despite the introduction of Mass Education Policy that advocates learner and resources-based education for primary, secondary and tertiary level education. Policies currently being implemented in Ethiopia may not be promising but due to the expected great active role of library and information science profession in the country's educational, social, political and cultural spheres; great attention is being focused by government on library and information science education in the country (Gojeh and Bayissa, 2008).

The Jimma University Library System (JULS) was established in 1999 and commissioned to promote instructions, research and public service goals of the entire university community through the expert provision of information, resources and services. In its attempt to achieve the mission and objectives of the University, the JULS sets out deliberately to identify and provide learning resources to teachers, researchers, and students, to manage available resources efficiently, effectively and economically; establish an environment conductive to study which caters for multiple learning styles, to liaise with users to establish their needs and to cooperate with management and other university services to meet these needs, to train users and staffs to develop their information exploitation skills for efficient and effective utilization of information resources, to carry out appropriate development work in library and information professionalism with the aim of improving libraries' multiple purpose services and maintain effective links with other systems at domestic as well as international level(Gojeh et al., 2012).

However, for such kind of achievement it need skill that help them to perform well and to become competitive. For improving the new and old employees in work place, it requires effective training that support to fill any gap hinder work effectiveness. Training need assessment are a critical stage for training section to deliver effective and reasonable program for every worker. But, origination miss this important area due to different factors, Therefore, the purpose of this study is to identify factors that affect training need Assessment in Jimma University College of Agriculture and Veterinary Medicine librarians.

\section{LITERATURE REVIEW}

\subsection{Definition of training}

Different authors have defined the term training using their own words though they have used different wordings, all definition convey the same meaning. The simplest meaning of training in the traditional training theory is the acquisition of knowledge and skills for presently known tasks. Training serves to help increase upward mobility within the organization, to adjust workers to the technological changes affecting the workplace, and often simply to introduce people to the world of work at the entry level. It is a planned and systemic effort to modify or develop knowledge, skill and attitude through learning experience, to achieve effective performance in an activity or range of activities. Its purpose, in the work situation, is to enable an individual to acquire abilities in order that he or she can perform adequately a given task or job and realize their potential" (Buckly and Caple, 2009; Ali, 2014).

Training is the process of developing qualities in human resources that will enable them to be more productive and contribute more in the achievement of organizational goal (Armstrong, 2009). Alkinani (2013), defined as Training is an organized process concerned with the acquisition of capability or the maintenance of existing capability. Different organizations go for training programs to improve productivity and quality, to increase organizational and employee morale, to motivate employees, to achieve financial gains, for prevention from industrial accidents, to provide wider awareness to employees that leads them to enhance their personal growth. Training is an important activity within an organization and that it is aimed at effecting positive changes in the trainees in terms of their knowledge, skills and attitudes, consequently improving their performance levels. In other words, training is a planned and continuous process for the existing and new employees, designed to meet the present and future skill and knowledge needs of individuals (Ali, 2014).

\subsection{Training needs assessment}

Training needs assessment (TNA) is the method of determining if a training need exists and, if it does, what training is required to fill the gap. TNA is also the process of collecting information about an expressed or implied organizational need that could be met by conducting training. The TNA process helps the trainer and the person requesting training to specify the training need or performance deficiency. TNA ensure the relevance of training activities for the target populations, consisting of professionals or types of professionals concerned to increase work quality and performance (Arti, 2017). Effective TNA involves systematic planning, analysis and coordination across the organization, to ensure that organizational priorities are taken into account, that duplication of effort is avoided and economies of scale are achieved.

Tobey (2005) offers a simple definition of training needs assessment, maintaining that it "is the process of identifying how training can help your organization reach its goals.” Du Plessis et al. (2010) argues that needs 
assessment "is all about finding whether training is necessary and if so, where, when and how." Du Plessis et al.'s defines "the systematic study of a problem or innovation, incorporating data and opinions from varied sources, in order to make effective decisions or recommendations about what should happen next", agree that it is not always necessary to train employees; rather, interventions might include other issues not training. There is also an agreement between the two definitions of TNA.

\subsection{Reasons for conducting a Training Needs Assessment}

Training can be expensive; therefore, it is critical that it is tailored to meet the specialized needs of the organization and of the individual trainees (Brown, 2002). TNA help to improve trainees' levels of knowledge, skills, and abilities. At the same time, any remaining deficiencies in their knowledge, skills, and abilities should be used as an input for the future TNAs as a rolling program essentially, of staff development (Ali, 2014). Swart et al. (2005) suggested that performance gap of employees can be bridged by implementing a relevant training method in order to develop particular skills and abilities of the workers thereby enhancing the performance of employees. Brown (2002) identifies four main reasons why needs assessment must be undertaken prior to training program are prepared, including the following: "to identify specific problem areas in the organization, to obtain management support, to develop data for evaluation and to determine the costs and benefits of training.

\subsection{Who Undertakes Training Needs Assessment?}

When training needs assessment is undertaken, there are those in the organization who must be involved in and how training needs assessment has to be conducted (Erasmus et al., 2006). Since needs assessments are conducted to decide whether training is required, it is imperative to involve the managers and the employees in the assessment process (Du Plessis et al., 2010). Grobler et al. (2006) argue that management involvement in needs assessment is important given that managers in general have accurate information concerning their employees' performance and managers are "in an improve position to assess the need for training in the work groups." Werner and DiSimone (2011) also refer to management involvement in training needs assessment, maintaining that immediate managers play a specifically important role in person analysis. Person analysis is that which "examines knowledge, skills, and current performance to determine who needs training.

\subsection{Training and Development}

Training and development, according to Estep (2008), highlights identifying, assuring, and helping develop, by means of planning learning, the main capabilities which allow individuals to perform existing or future tasks. Estep (2008) adds that training as solution on-the-job learning, coaching, or other measures of advancing individual learning. Mainly organizations go for training programs to improve productivity and quality, to increase organizational and employee morale, to motivate employees, to achieve financial gains, for prevention from industrial accidents, to provide wider awareness to employees that leads them to enhance their personal growth.

Werner and DeSimone (2011) argue that training and development focuses on changing or expanding individuals' knowledge, skills and attitudes, adding that training usually involves providing the workforce with the knowledge and skills to help them perform particular activities or jobs, as well as possibly changes in attitude might be attempted. Developmental activities, on the other hand, have a longer-term focus on the preparation for future work tasks and in the meantime increasing workforce's' competencies to perform their current jobs (Werner and De Simone, 2011).

\subsection{Barriers to Training Need Assessment}

Fairbairns (1991) suggests that many needs analysis technique fail to produce reliable information. She identifies two questions common to many needs analysis i) what skills, knowledge and/or personal attributes are important in your job and ii) in what skills, knowledge and/or personal attributes are you in "need" of training. Wright and Geroy (1992) like other articles high lighting the limitations of the training need assessment, they noted that "between $80 \%$ and $90 \%$ of the productivity improvement can be found in the work environment or cultures" and thus a "need-analysis-tied-exclusively-to training" is often ineffective. A needs assessment model utilized in their research with the Ontario Skills Program, they additionally make suggestions for the selection of a need's assessment model.

Abdullah (2009) suggested that absence of needs assessment and analysis is due to lack of expertise and it is irrespective of the size of firms. Other inhibiting factors mentioned by the organizations sampled include high employee turnover, the absence of a clear human resource development plans (HRD) plan and policy and the absence of a separate unit or section to handle employees' training and development. In the real world, there are many factors that influence the effectiveness of training need assessment and development in an organization. Birdi (2005) found that poor managerial support or an unfavorable departmental climate could limit the impact of creativity training with regard to influencing idea implementation. 
According to him training will be affected negatively if there is less support from department or there is unfavorable condition. Haslinda and Mahyuddin (2009) found that lack of support from top management and peers, employees' individual attitudes, job-related factors and also the deficiencies in training practice are the main factors which affect the effectiveness of training. If there will be less support from top management and peers, job is not going well or somehow there is problem in job and absence of training practice then there is less chance of effective training program.

\section{RESEARCH METHODS}

\subsection{Description of the Study Area}

Jimma University College of Agriculture and Veterinary Medicine (JUCAVM) geographically located at $346 \mathrm{~km}$ southwest of Addis Ababa in Jimma town. Jimma is bordered on the south by the Southern Nations, Nationalities and Peoples Region, the northwest by Illubabor, on the north by East Welega, and on the northeast Weast Shewa; part of the boundary with East Shewa is defined by the Gibe River. The mean maximum and minimum temperatures are $26.8^{\circ} \mathrm{C}$ and $11.4^{\circ} \mathrm{C}$, respectively. The mean annual rainfall of the area is $1500 \mathrm{~mm}$ (Negash et al., 2018).

Jimma University College of Agriculture and Veterinary Medicine (JUCAVM) was established in 1952 as Jimma Agricultural Technical School (JATS). JUCAVM, co-founder of Jimma University, is dedicated to advancing agricultural development through training, knowledge generation and service delivery in the country. The college trains high caliber professionals in broad areas of agriculture and veterinary medicine, both at graduate and undergraduate levels. The college upholds the values of educational relevance, transparency, social accountability, gender sensitivity, equity, community participation and empowerment.

JUCAVM comprises of five departments in the fields of agriculture namely, Horticulture and Plant Sciences, Animal Sciences, Natural Resource Management, Agricultural Economics, Rural Development and Agricultural Extension, Food Science and Post- Harvest Technology, and School of Veterinary Medicine. In addition to training the college also works on research, technology transfer and innovation, excellence in community service and engagement, internationalization and institutional collaboration and institutional transformation and good governance (https://www.ju.edu.et/jucavm/node/283).

Libraries have been around for a very long time and are traditionally seen as collections of information and services. JUCAVM library provides an endless variety of information resources related to many disciplines based on their specialization. It is to established for students in the campus to use for reading printed material, softcopy and to see online videos through internet access.

\subsection{Research design and Sampling techniques}

The study has employed a descriptive research design. To conduct this case study JUCAVM librarians were selected purposively. From the library 50 respondents were selected in simple random sampling method from the sampling frame.

\subsection{Data types and data source}

This survey study used both qualitative and quantitative data appropriately and through the integrating use of qualitative and quantitative data collection techniques and analysis procedures. The study was used both primary and secondary data sources, Primary data were collected from open and close ended questionnaire and interviewed. Secondary data obtained from related literature, scholarly written article review journals and browsing of the internet.

\subsection{Data Collection}

Background information was supplied by JUCAVM librarian staff member of manager. Before collecting the necessary data, the aim and the process was explained, the objectives stated, and the potential use of the results discussed. The questionnaire was prepared keeping the objectives of the study as a central point to collect necessary information. A questionnaire was developed using some, but not all, of the face-to-face interview questions. Some of the questions provided for respondent to answer in their own words.

The questions were formulated to contain information regarding demographic characteristics of the respondent (sex, age, marital status, level of education and work experience), their position, factors related to training need in the study area. Interview schedule, questioners and personal observation was used as a method of data collection for both quantitative and qualitative data. On the other hand, secondary data were derived from the findings stated in published documents and literatures related to the case study topic. These were based from the recent literatures such as; articles, journals and internet sources related to training need assessment.

\subsection{Data analysis}

Data collected through questionnaire, interview and observations were analyzed quantitatively and qualitatively 
using appropriate statistical tools and software to fulfill the objectives of the study. Quantitative data collected from the survey were analyzed using SPSS version 20. Descriptive statistics such as percentages and frequencies were used in the analysis of the data. Since the majority of questions were open-ended, all responses were recorded, like responses were grouped together, frequency of responses was determined and a corresponding percentage was calculated. As for some qualitative data, these were analyzed in systematic narration. Some data generated from the respondent also presented in table and graphs.

\section{Result and Discussion}

\subsection{Results}

4.1.1. Demographic characteristic JUCAVM librarians

The data obtained from the questionnaire, show that $70 \%$ of the respondent were females and the remaining $30 \%$ were males. As table 4 shows below, those respondents whose age is between 20-35 years consists $60 \%$ of the total sample size and $40 \%$ is consisted by those whose age is greater than 35 . The staff is dominated by Orthodox Christian religion followers who constitute about $70 \%$ of the respondents, whereas, the remaining $30 \%$ are Muslims. From this the majority $60 \%$ of the respondents have married and $40 \%$ of them are single. The family sizes are generally small. Survey results show that $40 \%$ of the respondents have no children, $40 \%$ have 1 2 children and $20 \%$ have 3 to 5 members.

\begin{tabular}{|c|c|c|c|c|}
\hline No & Item & Category & Frequency & Percent \\
\hline \multirow[t]{3}{*}{1} & \multirow[t]{2}{*}{ Sex of the respondent } & Male & 15 & 30.0 \\
\hline & & Female & 35 & 70.0 \\
\hline & \multicolumn{2}{|c|}{ Total } & 50 & 100.0 \\
\hline \multirow[t]{3}{*}{2} & \multirow[t]{2}{*}{ Marital status } & Single & 20 & 40.0 \\
\hline & & Married & 30 & 60.0 \\
\hline & \multicolumn{2}{|c|}{ Total } & 50 & 100.0 \\
\hline \multirow[t]{3}{*}{3} & \multirow[t]{2}{*}{ Religion } & Orthodox & 35 & 70.0 \\
\hline & & Muslim & 15 & 30.0 \\
\hline & \multicolumn{2}{|c|}{ Total } & 50 & 100.0 \\
\hline \multirow[t]{5}{*}{4} & \multirow[t]{4}{*}{ Age of the respondent } & $20-30$ & 15 & 30.0 \\
\hline & & $30-35$ & 15 & 30.0 \\
\hline & & $35-40$ & 5 & 10.0 \\
\hline & & $>40$ & 15 & 30.0 \\
\hline & & & 50 & 100.0 \\
\hline \multirow[t]{4}{*}{5} & \multirow[t]{3}{*}{ Family size } & No children & 20 & 40.0 \\
\hline & & 1-2 children & 20 & 40.0 \\
\hline & & $3-5$ children & 10 & 20.0 \\
\hline & \multicolumn{2}{|c|}{ Total } & 50 & 100.0 \\
\hline
\end{tabular}

Table 1 Sex, Age, Marital status and Religion

As the survey result revel that the majority $40 \%$ of the respondents have been working in the JUCAVM library for 6-10 years. Similarly, 20\%, 20\%, 10\% and 10\% of them served the in the library for more than 16 years. between 1-5 years, less than 1 years and 11-15 years respectively. From the interviewed sample size $10 \%$ of the respondents work at stock, $10 \%$ at reference and information, $20 \%$ at the store and $20 \%$ work at police position. The majority of the respondent were currently work at the position of circulation in the Library. Regarding on educational attainment the survey results indicate that, the majority of the respondents which represents $70 \%$ were Degree holders followed by Completed secondary and primary cycle which represents $20 \%$ and $10 \%$ respectively. 


\begin{tabular}{|c|c|c|c|c|}
\hline No & Item & Category & Frequency & Percent \\
\hline \multirow[t]{6}{*}{1} & \multirow{5}{*}{ Service year } & $<1$ & 5 & 10.0 \\
\hline & & $1-5$ & 10 & 20.0 \\
\hline & & $6-10$ & 20 & 40.0 \\
\hline & & $11-15$ & 5 & 10.0 \\
\hline & & $>=16$ & 10 & 20.0 \\
\hline & \multicolumn{2}{|r|}{ Total } & 50 & 100.0 \\
\hline \multirow[t]{6}{*}{2} & \multirow{5}{*}{ Work position } & Circulation & 20 & 40.0 \\
\hline & & Stock & 5 & 10.0 \\
\hline & & Reference and information & 5 & 10.0 \\
\hline & & Documentation and Book store & 10 & 20.0 \\
\hline & & Police & 10 & 20.0 \\
\hline & \multicolumn{2}{|c|}{ Total } & 50 & 100.0 \\
\hline \multirow{4}{*}{3} & \multirow{3}{*}{ educational attainment } & Degree & 40 & 80.0 \\
\hline & & Completed primary & 5 & 10.0 \\
\hline & & Completed secondary & 5 & 10.0 \\
\hline & & & 50 & 100.0 \\
\hline
\end{tabular}

Table 2 Service years, work position, and educational attainment

From those $30 \%$ of them hold the first degree in Business management followed by Accounting (20\%) and ICT (Information communication technology) (20\%). Only $10 \%$ of the employees were graduated human resource management degree as educational back ground. Only 20 those of the employees have educational background in ICT.

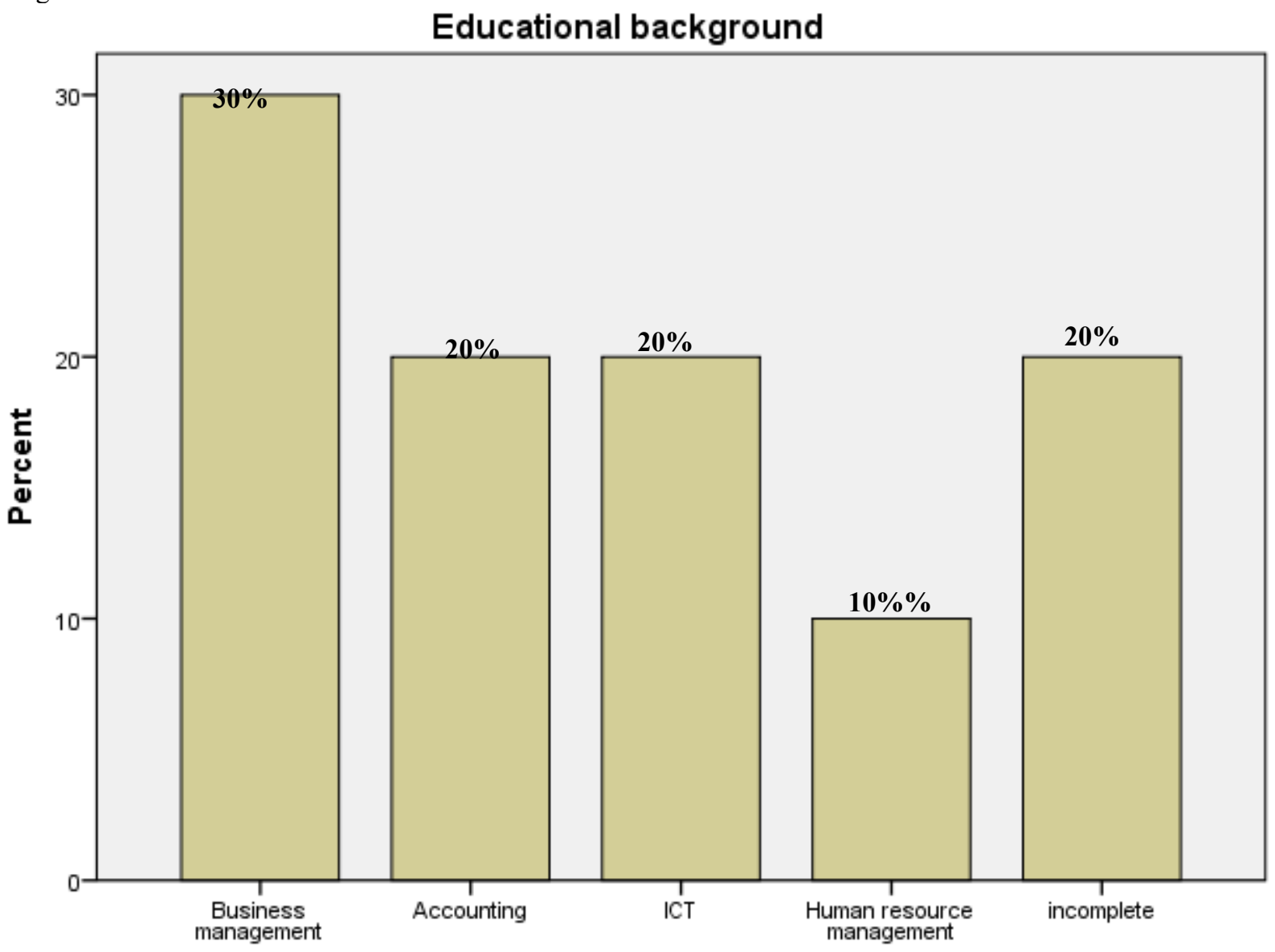

Educational background

Figure 1 Educational background of the respondents

4.1.2. Training in JUCAVM librarians

As the result show from the total $40 \%$ of the respondents get an inductions training about the organizations 
environments. The remaining majority of the respondent $60 \%$ claims that they didn't get any form of induction training during joined to the staff.

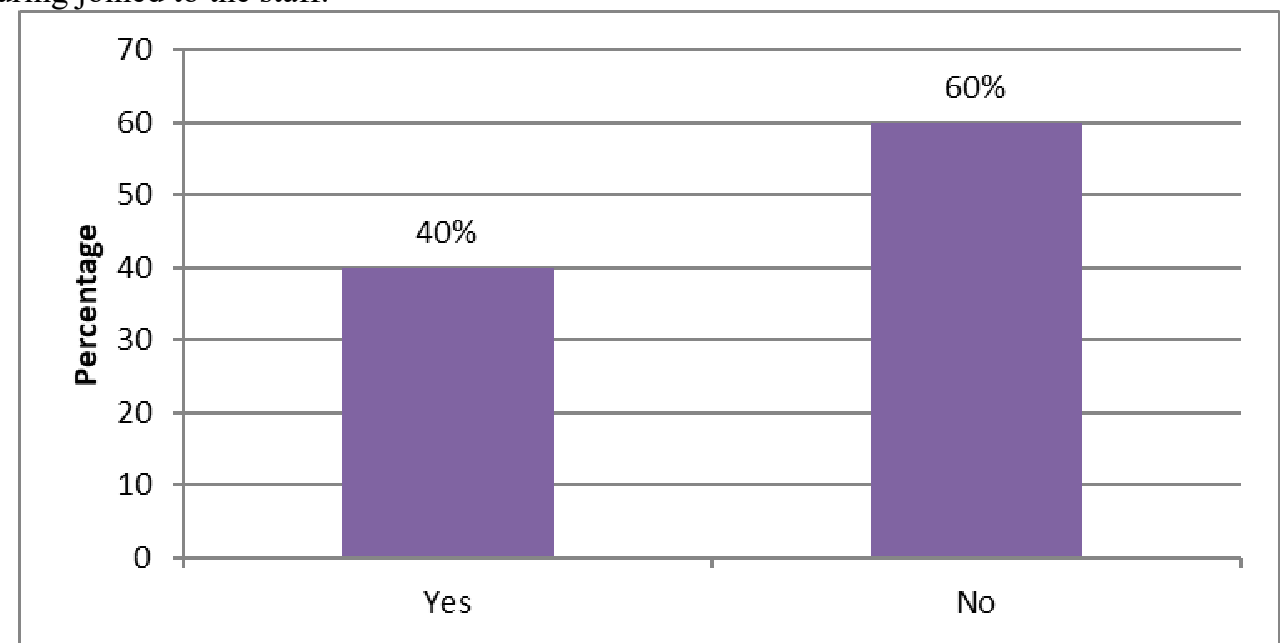

Figure 2 Response on induction training

The next emphasis on the survey was on training importance at workplace. The result indicates that majority of the respondents believe that training is an important that develop employee ability to perform any task. From the data $80 \%$ of the respondents agree that training is important for better performance; acquire new knowledge and skill for promotion. The $20 \%$ of the respondents were not agree on the significance of training at work place. The result comprehensively shows that most of the respondents agreed that competitiveness can be gained through training programs.

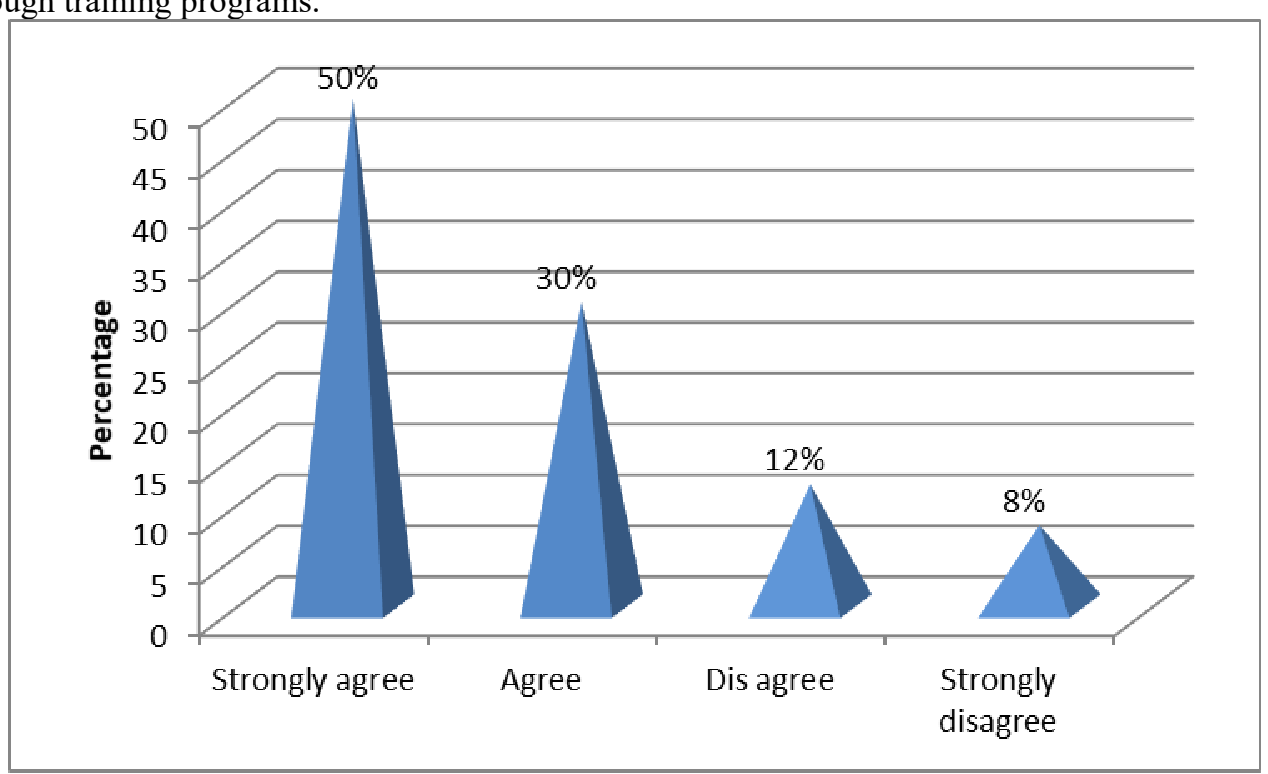

Figure 3 Importance of training

\subsubsection{Factors affecting training need in JUCAVM librarian}

Factors in general terms describe the challenges face in identifying training needs assessment of JUCAVM librarian staff. As the below table show that, among the respondents $70 \%$ agreed that the JUCAVM the university have no set a clear schedule for training program based on the need of the librarians were as $30 \%$ of the respondents said that it have clear schedule for training activities. In addition, on the interviewed asking the respondents whether their organization conducts a formal training needs assessment properly or not. As it is stated in the table $90 \%$ of the respondents agreed that there is no a proper formal needs assessment in their organization. In the contrary, the remaining $10 \%$ of the respondents believes that the training needs assessment conducted properly. 


\begin{tabular}{|c|c|c|c|c|}
\hline No & Variable & Item & Frequency & Percent \\
\hline \multirow{3}{*}{1} & \multirow[t]{2}{*}{ Clear schedule for training program } & Yes & 15 & 30.0 \\
\hline & & No & 35 & 70.0 \\
\hline & \multicolumn{2}{|l|}{ Total } & 100.0 & 100.0 \\
\hline \multirow{3}{*}{2} & \multirow{2}{*}{$\begin{array}{c}\text { Investigation to determine training } \\
\text { Need }\end{array}$} & Yes & 5 & 10.0 \\
\hline & & No & 45 & 90.0 \\
\hline & \multicolumn{2}{|l|}{ Total } & 50 & 100.0 \\
\hline
\end{tabular}

Table 3 Training schedule, investigation to determine training need

Participants were given the three common difficulties and were selected which is considered as difficult. It was found that lack of attention from higher manager due to workload is considered as the greatest challenge for staff about $50 \%$, followed by lack of proper training program $30 \%$ and Lack of facilities and logistics $20 \%$.

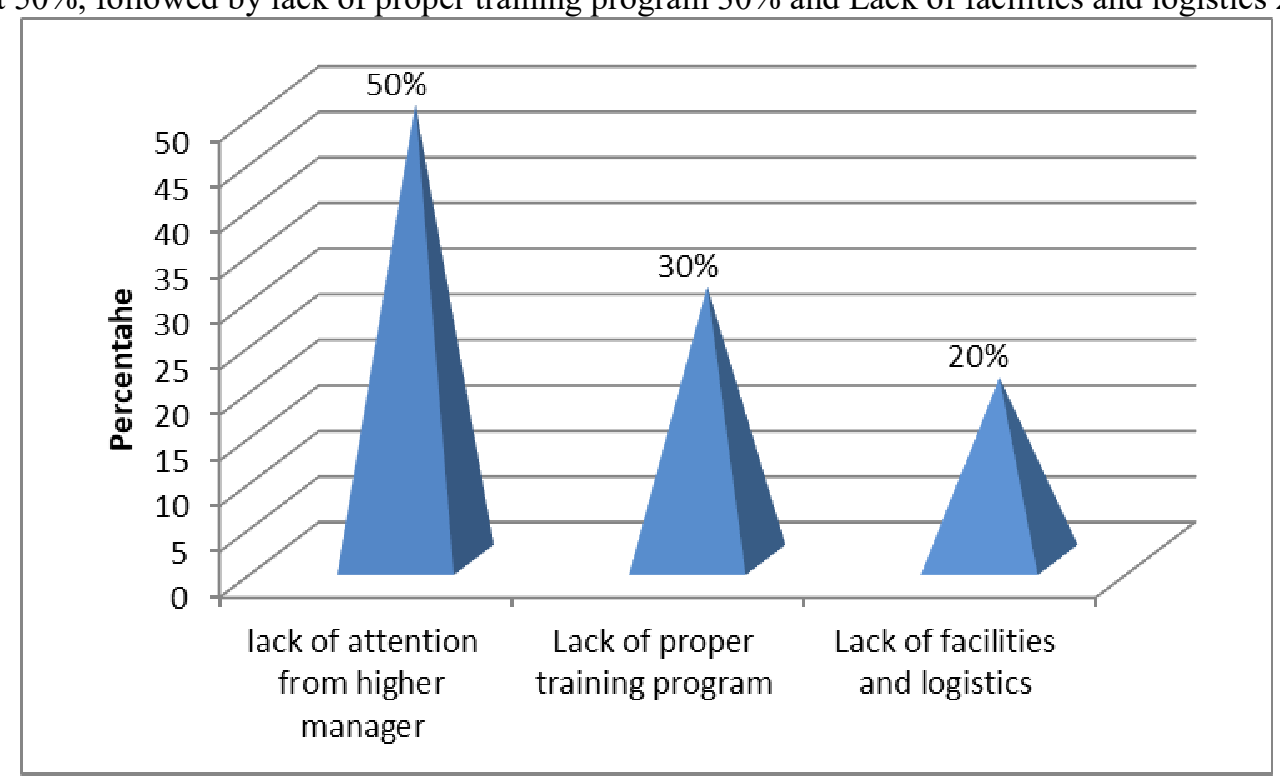

Figure 4 Factors affecting training need assessment

\section{Discussion}

In the result from the sampled respondents there are a greater proportion of the female respondents than male. This explains that the number of female employees were greater than male employees in JUCAVM library. As the majority of them between 20-30 years old, it indicates that the age composition of the JUCAVM is dominated by relatively young population. It is evidenced that the employees of JUCAVM librarians hold a range of educational qualification from primary completed to Degree level. This implied that the JUCAVM librarians' staff has fairly educated and skilled manpower employees. This is good opportunity to give any service and easily adapt the current requirement as librarians in the university. However, the majority of an employees $(80 \%)$ them have no full fill the direct requirement as a librarian. This implies that as the employees qualified with other filed, delivering training program related to the library science is critical through all work position.

On the other hand, since the majority of them are work in the library between 6 up to 10 years, this implies that the composition of work experience of the staff has an opportunity on the quality of delivering any service in the library. From the data outcome employers recognize the importance of regular training. Employees who are afforded the opportunity to gain knowledge from attending training sessions will be eventually better at how they perform. This finding also argues with Werner and DeSimone (2011); training focuses on changing or expanding individuals' knowledge, skills and attitudes, adding that training usually involves providing the workforce with the knowledge and skills to help them perform particular activities or jobs, as well as possibly changes in attitude might be attempted.

In addition, as of the responses of the interviewed from respondent every decision related to training is held by the university without information gathering about individual, there performance and the level of skill. The above analysis shows that the assessment of employees training need and skill gap is not satisfactory due three main factors. It was found that lack of attention from higher manager due to workload is considered as the greatest challenge that make the need assessment become poor. In addition to this lack of proper training program and Lack of facilities and logistics also the problems that identified by respondent. Related to training need assessment the university have no clear procedure that understood by the librarian.

Even based on data obtained, appropriate training program is not designed and developed based on 
employee's skill, knowledge, attitude gaps. This reinforcing the conclusion that there are no specific and systematic practices or procedures for determining training needs and programs in the JUCAVM library that encourage employees on decision making process on training need assessment. If an employee has no participate in any decision on the work place they became lose motivation to do their responsibility in desired and work standard. This idea also reported by Du Plessis et al. (2010); since needs assessments are conducted to decide whether training is required, it is imperative to involve the managers and the employees in the assessment process. This results also supported by Cummings and Worley, (2009) again argue that, employee participation in work place decisions in different issues including need assessment is important to enhance productivity by enhance communication and coordination among staff and the firm's departments, as well as helping integrate various jobs or departments which subscribe to the whole task; especially when they meet important individual needs; and employee intervention can increase employees competences.

In the other hand attention of manger to his/her employees have an effect on the job performance. Based on the result in JUCAVM library respondents identify lack of attention from the higher mangers due to workload is one of the main barriers that affect their training need. Author (Chris Musselwhite, 2008) also confirm that has discussed the vital connection between managers and employees. Performance is a key in the manager-employee relationship. "The manager-employee relationship has a critical impact on training need assessment and performance.

\section{Conclusion and Recommendation}

The assessment was made to identify factors affect training need assessment in the Jimma University college of Agriculture and Veterinary Medicine (JUCAVM). Questionnaire and interviews were the main methods of data collection in addition to personal observation. Primary data were collected from the total 50 respondents and analyzed. Based on the data presented and analyzed the most respondents understand the importance of training in the job place for improving work performance and to acquire new knowledge and skill for promotion.

According to interview held with respondent's lack of attention from the higher manager on training need assessment due to workload, lack of proper training program and Lack of facilities and logistics were the main reason for the failure of training need assessment. From the results of the study, it can be concluded that in Jimma University College Agriculture Veterinary Medicine related to librarian, fail in conducting proper training need assessment. They are failed in evaluation of each tasks and an individual where performed well or not. Based on the research result, the following recommendations were forwarded;

$>$ Assessing training needs is playing a very important role in identifying individuals who need to be trained, designing the program that relates to the needs of each individuals allocating the required time, determining the program objectives and the required skills and determining the required resources for implementing the program. So, as training is used to help the librarians to achieve its goals the upper, mid-level managers and the employees by itself should be involved in the need's assessment process.

$>$ Regarding on the training every decision is held by the university without a systematic and detail information gathering about individual, there performance and the level of their skill. Therefore, the university should be improving their performance assessment system to identify the exact performance deficiency caused by the absence of skills or knowledge that can be resolved by training.

$>$ As the result indicates that is not a regular system on delivering training program and weak in supervision with the higher university manager. In order to remain strategically positioned in the good providing service for college society both existing and new employees should be trained regularly based on their specific problem areas. The college should improve monitoring with higher managers and training access to the right people at the right time so that they build confidence in carrying out their job and raise their level of motivation and to make them more responsive to the customers' needs.

> Finally, in order to have an effective training practice the Jimma University and Veterinary Medicine should have to conduct each and every process properly give more emphasize on the identification of employee's skill, knowledge gaps and deliver trained based on the need identified. Therefore, since each process are interrelated, they need to be conducted in depth assessment with employees to know how they perform and what they remain to fill any gaps in the library.

\section{REFERENCE}

Abban, S. (2018). "Training and Development of Library Staff: A Case of Two University Libraries in Ghana" Library Philosophy and Practice (e-journal). 1794. https://digitalcommons.unl.edu/libphilprac/1794

Abdullah, H. (2009). "Training Needs Assessment and Analysis: A Case of Malaysian Manufacturing Firms", European Journal of Scientific Research, 37 (3), 351-360.

Ali Hamad Badi Ghufli (2014). Training Needs Analysis: An Empirical Study of the Abu Dhabi Police.Brunel University London.

Alkinani, H. (2013). Models of training needs assessment for the Iraqi construction industry, University of 
Salford

Armstrong, M. (2009). Armstrong's handbook of performance management: an evidence-based guide to delivering high performance, 4th edn, Kogan Page Publishers, London.

Arti B. (2017). A Literature Review on Training Need Analysis. IOSR Journal of Business and Management (IOSR-JBM).Vol. 19, no 10. Pp 50-56.

Birdi, Kamal S. (2005). No Idea? Evaluating the Effectiveness of Creativity Training, Journal of European Industrial Training, 29(2), pp. 102-111.

Brown, J. (2002). Training needs assessment: A must for developing an effective training program. Public Personnel Management, 31(4), 569-578.

Buckley, R. and Caple, J. 2009. The Theory and Practice of Training, 6th edn, Kogan Page, London; Philadelphia.

Chris Musselwhite. (2008). Three Ways to Build Successful Manager Employee Relationships Dangerous Opportunity: Making Change Work.

Cummings, T.G. and Worley, C.G. (2009). Organization Development \& Change. Ninth Edition. Mason, OH: South-Western Cengage Learing.

Du Plessis, A. Fredrick, H. and Goodwin, J. (2010). The importance of training and education for New Zealand entrepreneurs: Some empirical evidence. AGSE: 577-591.

Erasmus, B.J., Loedolff, P.V.Z., Mda, T. and Nel, P.S. (2006). Managing Training and Development in South Africa. Cape Town: Oxford University Press.

Estep, T. (2008). The evolution of training profession. In Beich, E. (Ed.) ASTD Handbook for Workplace Learning Professionals. Alexandria, VA: American Society for Training and Development.

Fairbairns, J. (1991). "Plugging the Gap in Training Needs Analysis", Personal Management, 23(2), 43-46.

Gojeh L.A. and Bayissa G. (2008). Brief communication Library and information science education in Ethiopia. Accessed at https://www.ajol.info/index.php/ejesc/article/viewFile/42997/26553

Gojeh L.A., Bayissa G., Fentahun A., Telale B., Ayde A., (2012). Staff development and training impacts on turnover pattern and retention in academic libraries in Ethiopian Universities. An unpublished research report submitted to Jimma University, Ethiopia.

Grobler, P. Warnich, S., Carrell, M.R., Elbert, NF. And Hatfield, R.D. (2006). Human Resource Management in South Africa. Third Edition. London: Thomson Learning.

Harris D and De Simon (1994). Human Resource Development. Fort Worth: The Dryden press. Henson, R. (2007). Looming Talent Shortage Rattles HR Departments. Retrieved on May 10, 2017.

Haslinda, A. and Mahyuddin, M.Y. (2009). The Effectiveness of Training in the Public Service, American Journal of Scientific Research, 6 (2009), pp. 39-51.

https://www.ju.edu.et/jucavm/node/283

https://www.ju.edu.et/library/node/23.

Salas, E., Weaver, S.J. and Shuffler, M.L. (2012). Learning, training and development in organizations. In Kozlowski, W.J. (Ed.) The Oxford Handbook of Organizational Psychology. Volume 1. New York: Oxford University Press, Inc.

Swart, J., Mann, C., Brown, S. and Price, A. (2005), Human Resource Development: Strategy and Tactics, Elsevier Butterworth-Heinemann Publications, Oxford.

Tobey, D.D. 2005. Needs Assessment Basics: A Complete, How-to Guide to Help You: Design Effective, OnTarget Training Solutions, Get Support, Ensure Bottom-Line Impact. Alexandria, VA: ASTD Press.

Werner, J. M. and DeSimone, R. L. (2011). Human Resource Development. Sixth Edition. Fort Worth: Harcourt College.

Wright, P and Geroy, G. (1992). "Needs Analysis Theory and the Effectiveness of Large-scale Government Sponsored Training Programs: A Case Study”, Journal of Management Development, 11-16. 